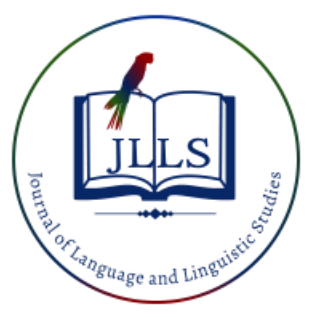

\title{
Pupils' perception towards gender differentiation and imbalance in secondary schools: Case study
}

\author{
Belaid Louiza ${ }^{a} 1$ iD, Sarnou Hanane ${ }^{b}$ iD \\ ${ }^{a}$ Abdelhamid Ibn Badis University, Mostaganem, Algeria \\ ${ }^{b}$ Abdelhamid Ibn Badis University, Mostaganem, Algeria
}

\section{APA Citation:}

Belaid, L., \& Sarnou, H. (2020). Pupils' perception towards gender differentiation and imbalance in secondary schools: Case study. Journal of Language and Linguistic Studies, 16(2), 1058-1069.

Submission Date: 14/03/2020

Acceptance Date:07/04/2020

\begin{abstract}
Gender imbalance still persists in developing countries in different fields. Education is one of the spaces in which gender imbalance continues to exist in Algeria, in terms of enrolment or achievement. This imbalance will unintentionally raise the issue of differentiation among genders at school. To this end, this research investigates the influence of gender differentiation on male pupils' success in secondary schools. The main objective is to examine to which extent gender bias could have an impact on learners' performance in foreign languages. As research instruments, a questionnaire and an observation are selected. Our sample is comprised of 131 pupils from Mosalaha and 80 pupils from Mohamed Boudhiaf Secondary Schools in the city of Tissemsilt- Algeria-. As for the observation, we have attended 10 English classes. The findings of this study reveal that differentiation exists in EFL classes and male pupils are threatened by the teachers' bias to females because of their number and interest in learning.

(C) 2020 JLLS and the Authors - Published by JLLS.
\end{abstract}

Keywords: gender imbalance; gender differentiation; pupils’ success; gender bias; foreign languages.

\section{Introduction}

Biologically speaking, human beings are not free from the effects of hormones during development. Actually, males and females are conforming creatures until the time sexual differentiation occurs. In social sciences, sex and gender are not identical because human males and females do not live in isolation but are social by nature. The social interactions of sexes, in a diversified culture, lead to the emergence of gender differentiation. For clarity, when-ever there is differentiation between genders; the question of gender inequality emerges. Accordingly, school is not free from gender inequality. Female and male pupils are merged in the same classroom; they follow similar orders though they are treated differently. Notably, the genders' roles represent a paradigm of attitudes, ways of thinking and expectations correlated to a peculiar sex. Further, many psychologists discern gender differences from sex differences, in which the former is associated with social roles, and the latter is characterized by physiology and anatomy. Although there are a myriad of irregularities, males and females do differ

\footnotetext{
${ }^{1}$ Belaid Louiza. Tel.: +213 696219572

E-mail address: belaidlouiza38@yahoo.com
} 
almost in ways that analogue gender stereotypes and this influence how the sexes behave at school and in the classroom. The differences are observed in their regular behaviors, ways of social interaction, academic potentials, motivation, and choices. They have many sources - first and foremost the family, peers, society and social media. However, teachers are not the main cause of gender role differences, but sometimes they affect them unintentionally through their responses and choices made if the sexes initialize a discipline problem or fail in the subject being taught. In this prospect, our work attempts to scrutinize the existence of gender differentiation in EFL classes and inquires for the impact of this imbalance of treatment on pupils' performance in general, and male pupils in particular.

\subsection{Gender Inequality}

As its name implies, gender inequality concedes that males and females are not equal in many ways (Pujar, 2016). Inequality is experienced differently depending on people's speech communities and life experiences. In fact, diversity that exists across cultures, societies and gender differences raises the concept of injustice between males and females, and gender is a factor which makes them different biologically, psychologically or even culturally (Han, Janmaat, Hoskins \& Green, 2012). We cannot disregard the co-existence of patriarchal societies, particularly in rural areas or small villages, whenever males dominate a field; inequality emerges in their favor (Sultana, 2011). The concept of inequality was further elucidated in Bedidi (2018) as:

\section{Following Algeria's independence, one of the major objectives of the Algerian government was to at once eradicate illiteracy and guarantee basic education for all children. Half a century later, this goal has almost been fully realized. Since then, inequality between the sexes has almost disappeared with regard to basic education. What was not expected, however, was the reemergence of a gender imbalance at the secondary and higher education levels - this time in favor of girls ( $p .85)$.}

Interestingly, though inequality serves men more than women, but the decision to abstract illiteracy -Algeria as an example- has reached unexpected outcomes which are, first, eradicating illiteracy in the country and, second, encouraging more females to further their career prospects, enroll and subscribe in higher percentages, graduate from higher positions and last be recruited in different fields and sectors. This latter causes a gender gap in which females' number is in progress in primary, secondary and university level; by contrast, males' rates are minimized (Bedidi, 2018).

\subsubsection{Gender Inequality in Favor of Women}

Many researchers assess the extent to which there is imbalance between men and women in achievement. It is acknowledged that the imbalance of genders is in favor of women whereby the success rate of girls in secondary schools and even university is increasing in comparison to boys. Furthermore, one step towards answering the question why women performance is higher, one should take "a closer look at the evolution of the gender ratio in each cycle of education: primary, secondary, and university" (Bedidi, 2018, p. 84). Equally, Lackner (2016) maintains that, apart from discrimination, competition is not regarded between genders in the same way, thus the genders' attitudes towards success vary. In this perspective, differentiation does not rise in a specific period; it is but an outcome of childhood experiences as Lackner (2016) explains "gender differences in competitiveness are formed early on in childhood and are relatively persistent, exerting a profound influence on an individual's future career" (p. 9). 
Bedidi (2018) puts forward that "in Algeria, the higher rates of graduation among girls have long been obscured" (p. 90), actually, she has stated that the high rate of female pupils in secondary schools or universities is probably due to their success ratio in middle school and secondary school cycles until they pass to university, women determination of education as a priority, women socialization, and obedience to school orders at an early age. In fact, not only girls dominate in secondary schools and universities more than the opposite gender, but they transcend them in their academic performance. The more they succeed the more their self-esteem, self-worth and confidence are promoted and they will be ambitious to further their studies to reach higher positions. Though these women come from patriarchal ${ }^{2}$ societies, they are highly encouraged to have a career (Berekashvili, 2012). By contrast, there are some men who do not have the sense of competing successful women, they prefer females who have a low educational level, as Badidi (2018) has explained "these men and women come from a society that is still largely dominated by an ancestral principle of male superiority, a principle that still strongly encourages men to marry women who are less educated than themselves" (p. 101).

\title{
1.1.2. Gender Bias
}

The presence of gender bias in the classroom could be observed among schools and the teachers' gender bias could have long term consequences on both genders (Srivastava, n.d.; Terrier, 2016). For Rettig (2002), pupils in the classroom do not receive the same treatment by their teachers and even the way questions are addressed to them differs. Because of the classes' size, the teachers teach to the average level not according to the genders' needs. In this respect, the concept of 'gendered curriculum' was introduced in education (Lee, 1996, Clark \& Millard, 2005; Moore, 2006; Berry, Rodríguez \& Craig, 2019) to identify the long-term aims of pupils regarding their interests at school and in the workplace. On the one hand, the success of females in humanities is considered as a consequence of 'gender stereotyping'; conversely, physical sciences stream is the field that is dominated by males per number and performance. In fact, even physical sciences stream, in the near future, is expected to be professionally dominated by females (Skidmore, n.d.). Yet, if female pupils are regularly exposed to biased teachers, they will establish a negative self-stereotype (Carlana, 2019). As clarified by Brodin, (2017):

\begin{abstract}
Gender bias in the form of dialogue, writing practices and distribution of talk often can be observed between teachers and students. For example, in her study from 2000, Chavez researched girls and boys behavior in the classroom during EFL lessons. Doing this, she noticed that girls were more likely to feel self-conscious and anxious as well as being more critical of their own performanc. (pp. 15-16).
\end{abstract}

Hence, it is the role of the teacher to assure that everybody in the classroom is included in the courses and any unusual silence or lack of participation does not necessarily entail the lack of motivation or interest but, rather, inclusion of all learners regarding their needs and interests make learners good performers whether males or females (Belaid \& Sarnou, 2019). As a matter of fact, boys intend to adopt anti-school masculine identities as a reaction to the feminised echoes of schooling and this might come up with conclusions of the provision of single-sex schools (Hughes, 2007) as an effective solution to the problem. Male pupils in a feminized context construct a school identity (West, Whittaker \& Crawford 2019) which is the opposite of who they are in order to be able to impose their character especially in

\footnotetext{
2 'patriarchy' literally means the rule of the father or the 'patriarch', and originally it was used to describe a specific type of 'male-dominated family' ... the male domination both in public and private spheres (Sultana, 2011, p. 2).
} 
the period of adolescence; therefore, separating genders from each other is another possible suggestion that might help in minimizing females' impact on males' behaviour in classes (Smyth, 2010).

Likewise, it was also raised that English and the languages are considered as the main school subjects whereby boys fail the most, and are not biologically disposed to learn (Swarbrick, 2002). Thus, boys' underachievement could be associated to the feminisation of the school curriculum; for this reason, females are being criticized for imposing their values and attitudes unconsciously on male pupils. More than that, it has been noted that girls are being treated as 'ideal learners' at schools whereas boys are marginalized to the extent that their engagement in class is not desirable (Simone, 2012).

In the same way, Mahony (n.d.) claims that "today's underachieving boy is tomorrow's unemployed youth. He is public burden number one, needing benefit in the world of global competition where governments want to get taxes down" (cited in Dean, 1998 as qtd in Smith, 2005) Obviously, it has been theorized that boys' low performance is not delimited to their failure at school, but it has long term outcomes in which their continuous failure entails their inability to find an appropriate job with an acceptable salary or no chance to be employed.

Sexton (1969), as well, has mentioned the danger of feminization and its serious effects on boys' performance. She has argued that "the feminized school simply bores many boys: but it pulls some in one of two opposite directions. If the boy absorbs school values, he may become feminized himself. If he resists, he is pushed toward school failure and rebellion" (p. 33) accordingly, she has categorized boys into two types. Males, who follow the school principals and orders, they unintentionally turn to be feminine in behaviour even in their way of thinking and adhering to school rules; whereas the second type, who will not follow the school orders the way they are, they are pushed indirectly to failure and then towards drop out.

Similarly, Leathwood \& Read (2009) put emphasis on feminization and its effects on male learners' performance. Epstein et al., (2002), as cited in Leathwood \& Read, believe that a myriad of debates about males' failure could be viewed as "a kind of globalized moral panic" (p. 19) whereby masculinity is menaced due to the reverse of the habitual gender order. The feminization of males became a constant concern to the extent that many scholars long for schools in which teachers were males par excellence "a strange nostalgia for school days when boys were boys and teachers were men regularly erupts" (ibid, p.19) Apparently, there is disapproval vis-a-vis females for overwhelming males' spaces which did not used to be theirs "women are seen to be increasingly encroaching upon a space that was previously the preserve of men alone" (Leathood \& Read, 2009, p. 19).

From the debate over females' success and males' failure academically, a gap might emerge in a feminine world; while girls are reaching high levels, their opposite sex find it hard to succeed and compete.

While women do earn the majority of degrees awarded each year, the gender
gap is dwarfed by the educational chasms related to racel ethnicity \& social
class. Therein lays the "crises". Low income \& minority men have a
particularly difficult time excelling academically, but their female
counterparts continue to lag behind whites as well (King, 2000, as qtd in
Leathwood \& Read, 2009, p. 20).

Obviously, women's achievement at school is better than men's achievement and the proof behind this are the degrees taken by females. It all depends on the social class, the social background and ethnicity which are in return based on cultural, social and language experiences. Speaking about social experiences, the failure of marriage in many societies and the high rates of divorce have an impact on 
females' perceptions. In a nutshell, broadening one's studies, if it is not a motivation, it is a negative reinforcement and marriage becomes an aversive stimulus.

\subsubsection{Gender Awareness}

Among the factors that influence pupils' success at school is gender. Scholars like Abrahams and Sommerkorn (n.d), Leathwood and Read (2009) and Badidi (2018) articulate that we cannot disregard living in a gendered world, thus gender as a concept should be seen as a social construct instead of a biological distinction. They have claimed that gender interferes in the relation between one's competencies in any field and one's self-esteem in their abilities in the respective field. For this reason, "promoting gender awareness in the classroom requires consciousness-raising at different institutional levels as well as amongst different groups of educators" (Bos \& Lehmann, 1995, p. 21). The problem that lays in the educational sector is the unawareness of teachers about genders and the roles they perform in the class. Actually, pupils are treated on the basis of their biological differences and what should be done in accordance to their sex, i.e. girls should follow the norms and behave with respect to femininity and boys could misbehave or raise their voices, yet their attitudes are considered as manly.

It is conventional that society has an impact on individuals especially teenagers. Nowadays many speech communities witness high complaints of divorce or repudiation (Khul'/ Khula) ${ }^{3}$ because marriage is more fragile. In fact, teenagers are aware of the fact that marriage is no longer working, especially if a woman is unemployed. Hence, hearing stories from their cousins, neighbors and even foreigners about the failure of marriage impulse females to further their studies and set a status in society. Therefore, if a woman will not get divorced, she will choose the 'Khula' (Pekkarinen; 2012; Algeria, 2013; Opening doors, 2013; Benchouiekh, 2019) consequently, the value of economic independence for women becomes a priority.

Likewise, according to the Mena development report (2013) -a research work In the MENA Region concerning equality among genders- it is emphasized that even though the norms place high values on women's role within their homes and their families. These norms are but a reflection of a patriarchal society through which women and men are "partners in a marriage but with separate roles" (p. 63). Actually, women's primary space of effect is perceived within the home; meanwhile, men are in charge of breadwinning and making decisive decisions in the public sphere. These perceptions are not unique to MENA societies, but are perhaps more pronounced worldwide. Still, these norms are changing, as education increases and the demographic balance shifts. The number of females, the change of interest and the openness to the world, and as a reaction to patriarchy, females are stepping forward in education, in their homes, and in the public sphere.

\section{Method}

\subsection{Context}

In order to conduct this study, a multi cluster sampling is carried out to select schools and pupils from Tissemsilt-Algeria. In this perspective, two secondary schools are chosen, Mosalaha and Mohamed Boudhiaf Secondary Schools. We have selected final classes' learners because they are aware enough of the gender bias of their teachers either at this level or in middle and primary school cycles.

\footnotetext{
${ }^{3}$ Khula is a procedure in which a woman can divorce her husband in Islam, by returning from the dower all that she received from her husband.
} 


\subsection{Instruments}

A mixed method approach is applied in this endeavor; a qualitative approach whereby attitudes towards gender bias are highlighted and a quantitative approach in which certain percentages are provided. The data collection instruments used in this investigation are a questionnaire and an observation to collect the necessary data. The questionnaire is a set of open ended and close ended questions highlighting numeral and ordinal variables which revolve around the pupils' perception towards their teachers' bias in the classroom. As for the semi-structured observation, we have attended English classes for one year, and set a checklist identifying the frequent instances of gender differentiation.

\subsection{Sampling}

In our qualitative investigation, a sample of 131 pupils has been selected from the secondary school of Mosalaha and 80 pupils have been selected from Mohamed Boudhiaf Secondary School, in the region of Tissemsilt, Algeria. Our population is selected from four streams; In Mohamed Boudhiaf we have, $26 \%$ foreign languages, $28 \%$ philosophy, $31 \%$ sciences and $15 \%$ mathematics. Whereas, at Mosalaha Secondary School, we have $11 \%$ from foreign languages, $22 \%$ Mathematics, $30 \%$ philosophy and $37 \%$ from sciences. In both schools their age ranges between 16 and 18. It is noteworthy to mention that male pupils' number is lower than females' number in both schools, since $76 \%$ are females and $24 \%$ are males in Mosalaha; whereas, $41 \%$ are males and $59 \%$ are females in Mohamed Boudhiaf Secondary School.

\section{Results}

Gender differentiation is not easy to be identified, but our sample of pupils have expressed their views differently while our observation confirms that there is bias to females more than males because in both schools female pupils are highly responsive in comparison to their counterparts. In this vein, from the collection of data we have found the following results.

First, being biased to one gender over another in the classroom could create sensitivity between genders especially when females outnumber males in the class. Conventionally, teachers communicate with pupils who are active in the classroom, participate and correct activities. If these pupils represent the female gender, teachers would participate only with them and neglect minority groups who are passive and indifferent, especially pupils who sit at the back of the classroom and are considered as goof-offs. According to figure 1,32\% of pupils claim that their teachers are biased towards females whereas $68 \%$ asserts that they are not. On the contrary, $15 \%$ argues that the teachers are biased towards males while $85 \%$ refutes this claim. Apparently, because the majority of pupils are females, they disapprove this articulation; however, the majority of pupils assert that their teachers are not biased to males because of their disruption in the classroom, passivity, low performance and even indifference. 


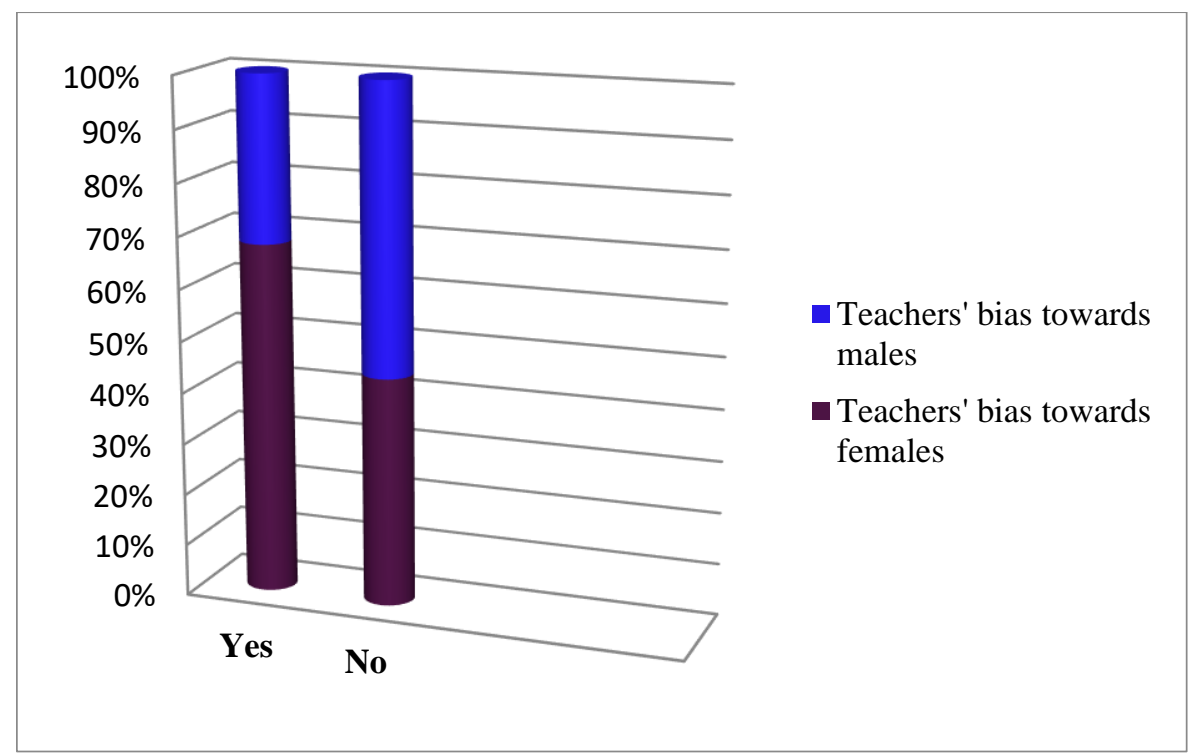

Figure 1. Teachers' bias towards genders in Mohamed Boudhiaf School

Second, as indicated in figure 2 below, $91 \%$ of pupils of Mosalaha argue that their teachers are not biased towards males, whereas $9 \%$ states that they are. Alternatively, $63 \%$ of learners put forward that their teachers are not biased towards females, but $37 \%$ confirms this claim. The same as the previous school, the majority of pupils are females, and though $37 \%$ is not a high percentage, but learners believe that the instructors have a certain bias towards females, especially when they are good performers at school in comparison to many female pupils who are passive and indifferent; more particulary, those who belong to a literary steam like philosophy in which they show no interest in the English classes. However, the majority controverts tendency towards males because there is a consensus among teachers that the majority of male pupils are disrespectful in the classroom and have no interest in learning languages, besides their inadequate behavior in all streams, literary or scientific.

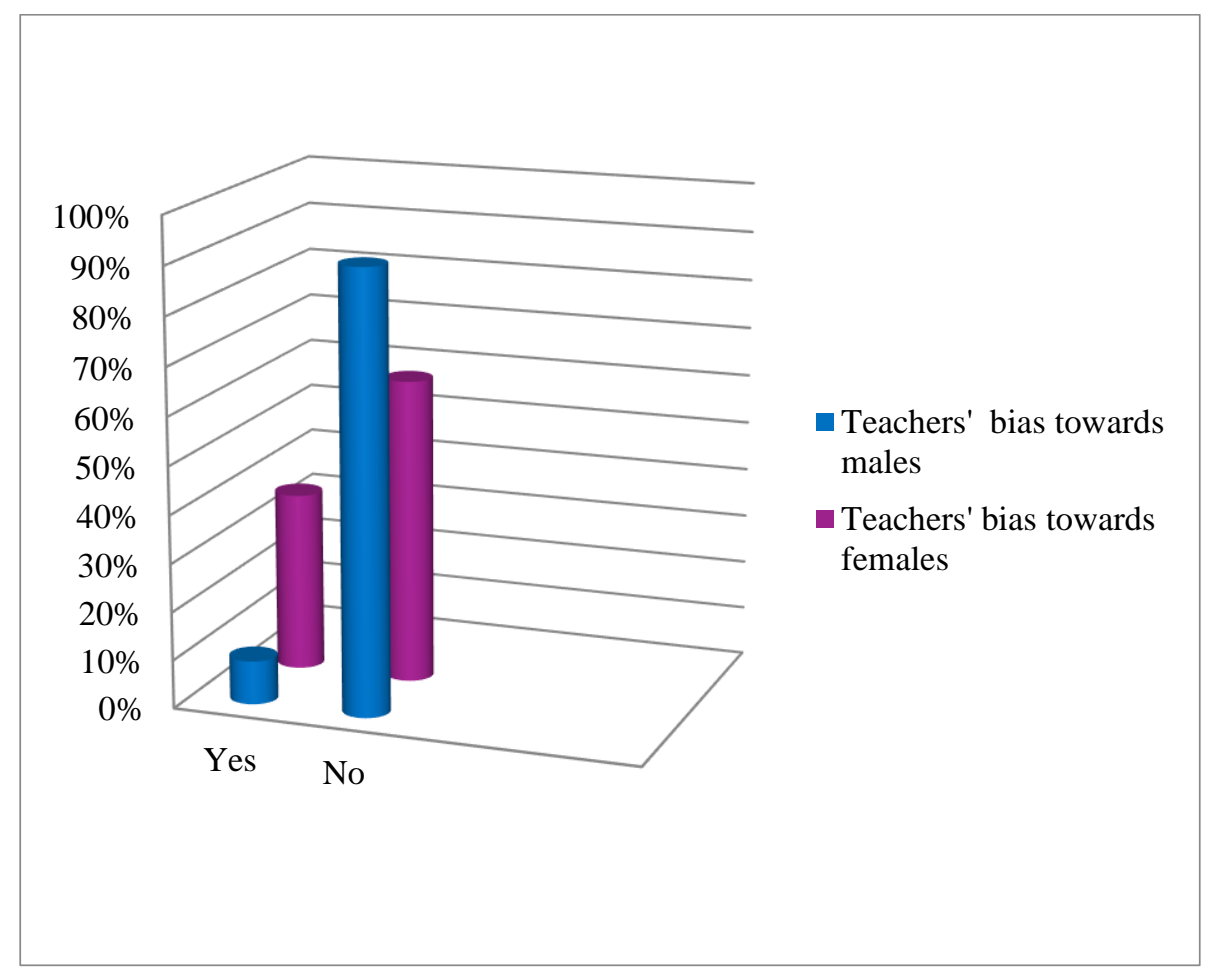

Figure 2. Pupils' opinions about their teachers' bias towards genders in Mosalaha School 
Gender equity is quite important to a far-reaching extent; one of its aims is to keep male pupils at school and make them good achievers too. Actually, we can not deny the increased number of females in both schools and in all the schools of Tissemsilt. As teachers, being biased to one gender over another might cause problems of inequality in the classroom, and pupils are aware enough of this. As a matter of fact, pupils are able to identify the extent to which they are disregarded or considered in comparison to females. Table 2.1 and figure 2.1.1 display the options of learners at Mohamed Boudhiaf School regarding male pupils continuous failure.

Table 2.1. Pupils' opinions about the outcomes of males' continuous failure in Mohamed Boudhiaf

\begin{tabular}{|ll|l|}
\hline a) & Male pupils will do their best and compete females & $39 \%$ \\
\hline b) & Female pupils will have more opportunities of having jobs & $66 \%$ \\
\hline c) & Male pupils will leave school & $63 \%$ \\
\hline d) & High rate of female learners will graduate & $55 \%$ \\
\hline e) & School will be feminized for 100\% & $53 \%$ \\
\hline
\end{tabular}

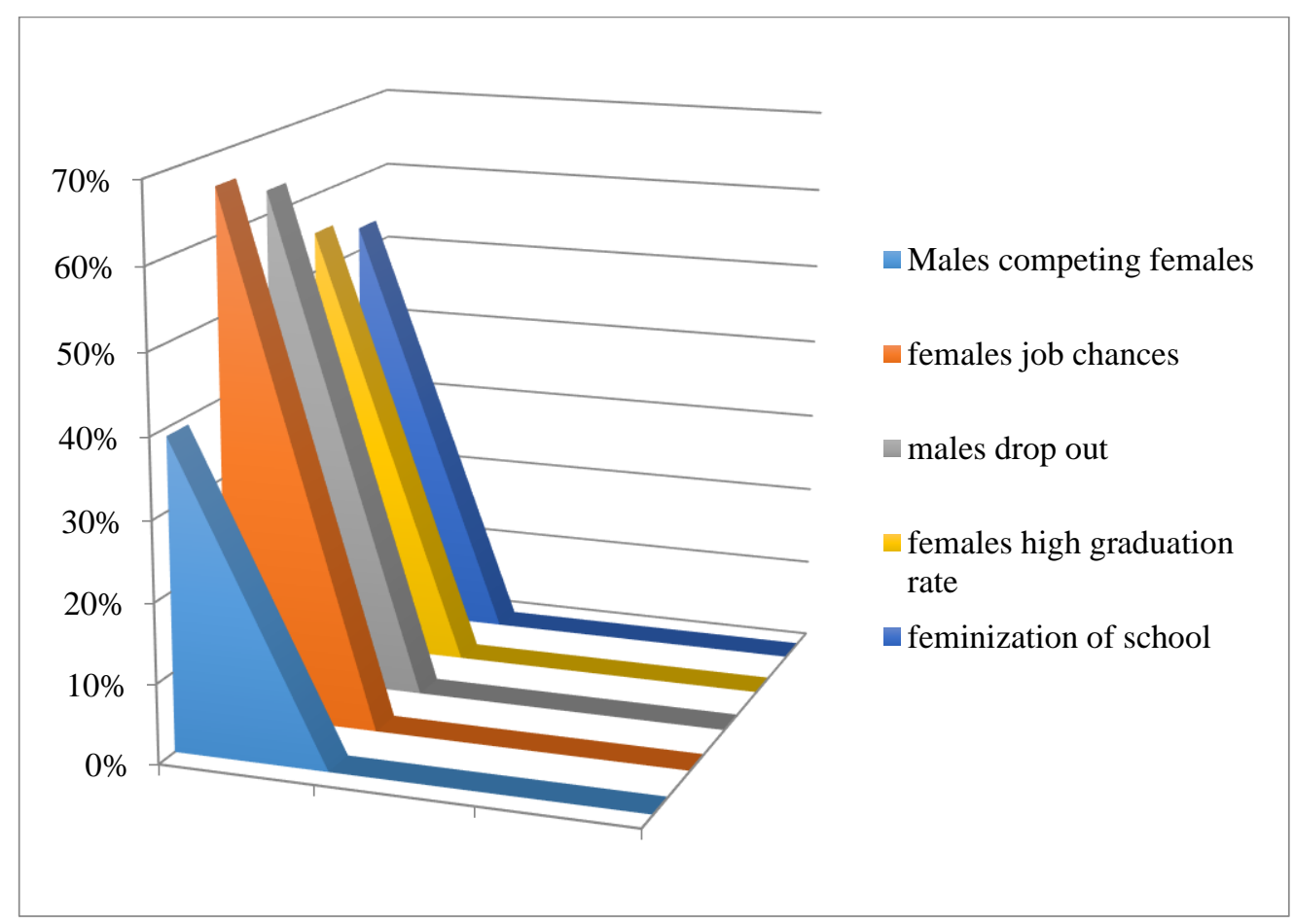

Figure 2.1.1 The perspectives of learners towards males' school failure

Apparently, the high percentage (66\%) opts for the current situation that is seen in our societies which is the chances of females in the workplace that are in progress in comparison to males. Most of pupils are aware of the fact that females have more chances, especially if male pupils keep failing and dropping out of school, they will not have a recognized degree as a persistent female. However, male pupils believe that even if they apply for a job, they will not be accepted particularly when they hear about or know people (males) who graduated but they are still unemployed; this latter is going to make them lose interest and enthusiasm respectively. $63 \%$ of pupils believe that continuous failure would lead to dropout and quitting school early; 55\% of learners assume that whenever boys are excluded from school, a high number of girls will join university, graduate and dominate the workplace. 53\% thinks that schools 
will be feminized whereas a low percentage, $39 \%$, asserts the possibility of boys to work hard after each failure experience and achieve good results; though none of the males selected this choice.

In parallel, at the secondary school of Mosalaha, $87 \%$ thinks that the more males fail and leave school, qualification to obtain jobs will be in favour of females. $72 \%$ of pupils believe that females will graduate with high rates. $37 \%$ of our sample claims that males are going to leave school early whereas $29 \%$ maintains that schools will be feminized because the number of girls is rising. Similar to the previous school, $17 \%$ of Mosalaha pupils articulate that it is probable that males will contest females to succeed. Our sample, in both schools, has emphasized that females have the advantage to find jobs in the future, first, because of their number, second, because of their perseverance to earn high degrees, and third, because of the claim of many pupils, especially males, that there is bias as well when it comes to recruitment whereby females are accepted while males are rejected because of gender and not because of qualifications or diploma. Table 3.1 and figure 3.1.1 explain the rate of each choice.

Table 3.1. Learners' perspectives of the outcomes of boys' failure in Mosalaha School

\begin{tabular}{|c|c|}
\hline a) Male pupils will do their best and compete females & $17 \%$ \\
\hline b) Female pupils will have more opportunities of having jobs & $87 \%$ \\
\hline c) Male pupils will leave school & $37 \%$ \\
\hline d) High rate of female learners will graduate & $72 \%$ \\
\hline e) School will be feminized for $100 \%$ & $29 \%$ \\
\hline
\end{tabular}

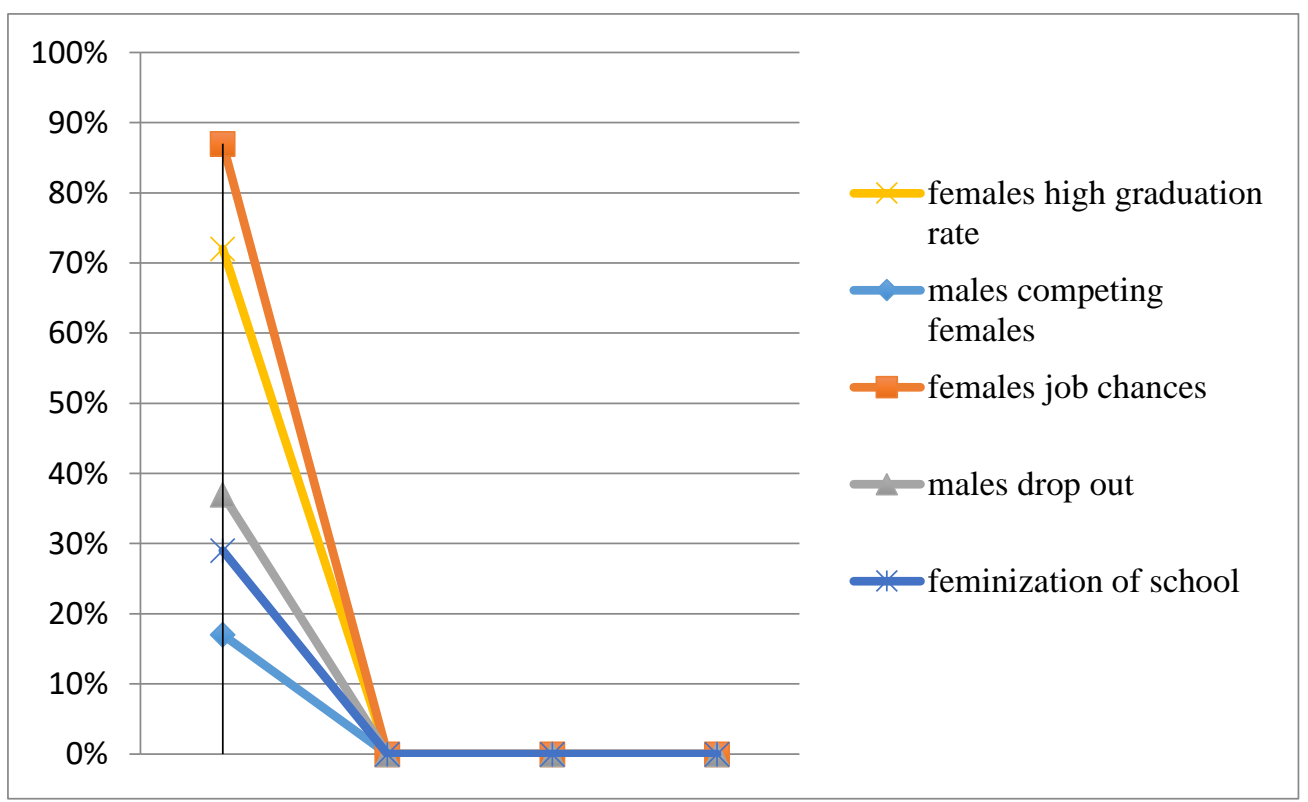

Figure 3.1.1 Pupils' perception towards males' continuous underachievement.

Notably, in both schools, the concept of gender gap is emphasized and the high number of females, whether they are pupils or teachers, will unintentionally affect male pupils' perspectives and identities. Males, in different societies, attempt to keep their masculine identity and follow the norms, but in case they feel that there is a possibility of being de-traditionalized, they prefer to leave school and opt for another space through which their gender role is secure (Belaid \& Sarnou, 2018) one possible proposal to motivate male pupils at school is to introduce gender awareness in the teachers' training program, 
because the concerns of inspectors during training days address the 'ideal student' and how to understand $\mathrm{SARS}^{4}$ as a lesson plan technique to adjust the courses. This didactic technique is functional only if pupils are motivated to learn foreign languages and do not have failure experiences in previous levels. Nowadays, the $21^{\text {st }}$ century learner is well versed in technology and s/he conscious about the common problems of society. This early awareness of genders makes them more sensitive at school and in the classroom. In this prospect, raising gender awareness and realizing equity in the classroom are necessary to create a learning climate through which a positive rapport is built between learners and teachers or vice versa.

\section{Conclusion}

School is another space whereby gender differentiation emerges. Gender imbalance exists worldwide; that is to say, in all societies women are more than men in number. At school, females' number exceeds that of males, in all streams and all levels. Thus, the more there is a gap between genders the more differentiation is recognized. In our work, we attempted to find out the extent to which teachers of English are biased towards females and how pupils see the gender gap and its impact on male pupils. From the questionnaire and the observation we employed, results reveal that male pupils are deeply affected by the number of females in the classroom and in society because they are treated worse than females; additionally, they believe that their chances in the work place are confined; they have no intention to compete females if they fail as they choose to abandon school at an early age if their achievement does not qualify them to pass into another educational degree. Hence, gender differentiation in an EFL classroom should be reconsidered carefully because male pupils, as teenagers, are aware of the gap in comparison to their opposite sex and feel unsafe in the classroom and in society. Thus, it is prerequisite to encourage them to do their best and provide them with motivating feedback. If all the social conditions stimulate females to broaden their studies, it is an obligation to create other conditions that keep male pupils at school.

\section{Ethics Committee Approval}

The author(s) confirm(s) that the study does not need ethics committee approval according to the research integrity rules in their country (Date of Confirmation: April 02, 2020).

\section{References}

Abrahams, F. F., \& Sommerkorn, N. I. (n.d.). Promoting gender awareness in the classroom: An example from Germany, University of Hamburg. pp. 8-24.

Algeria country of origin information (COI) report. January 17, 2013. United Kingdom: UK Border Agency.

Bedidi, O. Z. (2018). Gender inequity in education in Algeria: When inequalities are reversed. Journal of Education \& Social Policy, 5 (2). pp. 84-105. Université Paris Diderot- Paris 7. doi:10.30845/jesp.v5n2p10

\footnotetext{
${ }^{4}$ SARS is an acronym which stands for select, add, reject, substiture. It is a technique in didactics that aims to clarify lectures for learners.
} 
Belaid, L., \& Sarnou, H. (2018). Feminization of schooling: Understanding the detraditionalized gender. Brolly. Journal of Social Sciences, 1 (1), 115-124.

Belaid, L., \& Sarnou, H. (2019). University for all: Including special needs learners in education.The Journal of Studies in Language, Culture and Society, 1(2), 115-124.

Benchouiekh, S. (2019). Practical aspects of consensus on khula 'in the Algerian family code. مجلة الاجتهاد . 8 (4), 261-280.

Berry, R. T., Kalinec-Craig, A. C., \& Rodriguez, A. M. (2019). Latinx curriculum theorizing. United Kingdom: The Rowman \& Littlefield Publishing group.

Berekashvili, N. (2012). The role of gender-biased perceptions in teacher-student interaction. Psychology of Language and Communication, 16 (1), 39-51. DOI: 10.2478/v10057-012-0004-x

Brodin, A. (2017). Gender bias and teachers in the EFL classroom in 4-6. Grundlärarexamen med inriktning mot årskurs 4-6, 240hp

Bos, W., \& Lehmann, H. R. (1995). Reflections on educational achievement: Papers in honor of T. Neville Postlethwaite. New York: Waxmann.

Carlana, M. (January, 2019). Implicit stereotypes: evidence from teachers' gender bias. Cambridge: Harvard Kennedy School, Kennedy.

Clark, A., \& Millard, E. (2005). Gender in the secondary curriculum: Balancing the books. London and New York: Routledge.

Han, C., Janmaat, J.G., Hoskins, B., \& Green, A. (2012) Perceptions of inequalities: Implications for social cohesion, published by the Centre for Learning and Life Chances in Knowledge Economies and Societies at: http://www.llakes.org

Hughes, A. T. (2007). The advantages of single-sex education. National forum of educational administration and supervision journal. 23(2), 5-14.

Lackner, M. (2016). Gender differences in competitiveness: To what extent can different attitudes towards competition for men and women explain the gender gap in labor markets? Johannes Kepler University Linz, Austria, IZA World of Labor.doi: 10.15185/izawol.236

Leathwood, C. Read, B. (2009). Gender and the changing face of higher education: A feminized future? England: Society for Research into Education and Open University Press.

Lee, A. (1996). Gender, literacy, curriculum: Re-writing school geography. New York: Taylor and Francis.

Moore, A. (2006). Schooling, society and curriculum. London and New York: Routledge, Taylor and Francis group.

Openning doors: Gender equality and development in the Middle East and North Africa. (2013). Mena Development Report. Washington, DC: The World Bank.

Pekkarinen, T. (2012). Gender differences in education. Germany: The Institute for the Study of Labor (IZA).

Pujar, S. (April, 2016). Gender inequalities in the cultural sector: report. Belgium: Culture action Europe.

Rettig, R. P. (2002). Quantum leaps in school leadership. United States of America: Scarecrow Press. 
Sexton, C. P. (1969). The feminized male: Classrooms, white collars, \& the decline of manliness. Michigan: Random House.

Simone, A. J. (2012). Addressing the marginalized student: The secondary principal's role in eliminating deficit thinking. Published doctoral dissertation. University of Illinois at Urbana-Champaig, Illinois.

Skidmore, L. (n.d.). Women in science: Past and future trends. pp. 45-55.

Smith, E. (2005). Analyzing underachievement in schools: Empirical studies in education. London and New York: Continuum international publishing group.

Smyth, E. (2010). Single-sex education: What does research tell us? Revue française de pédagogie, 171, 47-58. DOI: $10.4000 / \mathrm{rfp} .1896$

Srivastava, G. (n.d.). Gender concerns in education. NCERT. 1-27.

Sultana, A. (2011). Patriarchy and women's subordination: A theoretical analysis. The Arts Faculty Journal, Department of Political Science, University of Dhaka. 1-18.

Swarbrick, A (2002). Teaching modern foreign languages in secondary schools: A reader. London and New York: Routledge Falmer.

Terrier, C. (2016). Boys lag behind: How teachers' gender biases affect student achievement. Germany: Forschungsinstitut zur Zukunft der Arbeit Institute for the Study of Labor.

West, S. M., Whittaker, M., \& Crawford, K. (2019). Discriminating systems: Gender, race and power in AI. AI Now Institute. Retrieved from: https://ainowinstitute.org/ discriminatingsystems.html.

\section{Ortaokullarda öğrencilerin cinsiyet farklılaşması ve dengesizliğine ilişkin algılar1: Örnek olay}

\section{$\ddot{O} z$}

Cinsiyet dengesizliği gelişmekte olan ülkelerde farklı alanlarda hala devam etmektedir. Eğitim Cezayir'de kayıt veya başarı açısından cinsiyet dengesizliğinin devam ettiği alanlardan biridir. Bu dengesizlik istemeden okuldaki cinsiyetler arasındaki farklılaşma konusunu gündeme getirecektir. Bu amaçla, bu araştırma cinsiyet ayrımcılığının erkek öğrencilerin ortaokullardaki başarısı üzerindeki etkisini araştırmaktadır. Temel amaç, cinsiyet yanlılığının öğrencilerin yabancı dillerde performansını ne ölçüde etkileyebileceğini incelemektir. Araştırma araçları olarak bir anket ve gözlem seçilmiştir. Araştırmamızın örneklemi Mosalaha'dan 131 ve Tissemsilt-Cezayir- kentindeki Mohamed Boudhiaf Ortaokullarından 80 öğrenciden oluşmaktadır. Gözlem için 10 İngilizce dersine katııındı. Bu çalışmanın bulguları, EFL sınıflarında farklılaşmanın olduğunu ve erkek öğrencilerin, sayıları ve öğrenmeye ilgileri nedeniyle öğretmenlerin kızlara karşı önyargıları tarafından tehdit edildiğini ortaya koymaktadır.

Anahtar Sözcükler: cinsiyet dengesizliği; cinsiyet farklılaşması; öğrencilerin başarısı; cinsiyet yanlılı̆ı; yabancı diller

\section{AUTHOR BIODATA}

Belaid Louiza is a doctoral student in sociolinguistics at the University of Abdelhamid Ibn Badis, Mostaganem. She holds a Master Degree in Didactics of English and Applied Linguistics since 2015. Her interest areas include language teaching, Sociolinguistics and gender studies.

Hanane Sarnou, Ph.D Candidate, English Department, University of Mostaganem- Algeria. 